\title{
FACTORIAL STRUCTURE OF PHYSICAL REHABILITATION GROUP STUDENTS' COMPLEX FITNESS
}

Sobko I. N., Ulaeva L.A., Yakovenko Y.A.

Simon Kuznets Kharkov National Economic University

\begin{abstract}
Purpose: differentiation of physical education process on the base of morphological-functional state and physical fitness indicators, psycho-physiological potentials of physical rehabilitation group's students. Material: $501^{\text {st }}$ year students of 17-18 years' age participated in the research. Tests for assessment of students' morphological-functional state were used. Psycho-physiological testing was carried out with the help of computer program. Results: we marked out 5 factors, which characterize main components of students' physical condition. It was determined that low level of students' physical and functional potentials weakens functioning of organism's most important functions. It was found that the most important factors in complex fitness of physical rehabilitation group's students are power and functional potentials. Conclusions: it is necessary to purposefully work on formation of students' comprehensive motor potential. Results of the research permit to rationally distribute physical education means and methods in practical trainings of physical rehabilitation group.
\end{abstract}

Key words: physical rehabilitation, students, complex fitness, factorial analysis.

\section{Introduction}

Improvement of national higher educational system conditions optimization and upgrading of physical education. To day there is demand in development of effective means and methods, oriented on increase of students' education quality, considering age and personality aspects [1, 7, and 17]. It will create necessary preconditions for development of students' steady interest in independent motor functioning, formation of rational choice and usage of physical education means in their life activity skills [1, 3, 23, and 26]. This problem is rather urgent for physical education of boys [17] and girls [10].

Assessment of main group students' different kinds of sports sportsmen's morphological-functional state, physical fitness and psycho-physiological potentials was realized in many works [5, 6, and 8]. For determination of students' complex fitness characteristics scientists apply factorial and cluster analysis [6, 12, and 17]. There are data about application of special technologies in physical education of hard hearing girls [9, 11].

In physical education theory, there is intensive search of modern means, which would increase students' educational effectiveness (meaning students, trained in physical rehabilitation groups) [2, 3, 17, 18, 21, and 25]. Scientists regard questions of methodic and organization of special health groups and therapeutic physical culture groups students' physical education $[4,15]$. They show positive influence of physical exercises and sports games elements on development of these groups' students' motor qualities and coordination $[13,18]$.

The program of discipline "Physical education" does not completely open content and orientation of education process for physical rehabilitation groups' students [16]. Recommendations on organization and technology of such trainings' construction have general character. It results in discrepancies and ambiguity in approaches to organization and building of practical classes with such contingent [22, 27, and 28]. Different character of students' diseases made to search adequate approaches to trainings. The more completely demand o such groups' students will be known the more significantly the methods of physical exercises' practicing will differ $[2,18,28]$.

Thus, for effective work with physical rehabilitation group students, teachers shall have information about morphological-functional and physical fitness indicators, about students' psycho-physiological potentials. In its turn it will help to determine appropriate means and methods of physical education for this contingent.

\section{Purpose, tasks of the work, material and methods}

The purpose of the work is differentiation of physical education process with usage of adequate means and methods on the base of morphological-functional state and physical fitness indicators, psycho-physiological potentials of physical rehabilitation group's students.

(c) Sobko I.N., Ulaeva L.A., Yakovenko Y.A., 2016 doi:10.15561/20755279.2016.0205 
The methods of the research: we used tests for assessment of morphological-functional state (body length, body mass, blood pressure, heart beats rate in rest), physical fitness (dynamometry of right and left hands; ball's passing in pairs for $30 \mathrm{sec}$. from 3 meters' distance; keeping legs under angle of $45^{\circ}$; bending and unbending arms in elbows with load of $1 \mathrm{~kg}$ for $30 \mathrm{sec}$.; throwing of tennis ball to target from 6 meters' distance), Romberg's test. Psycho-physiological testing was carried out with computer program "Psycho-diagnostic" [1]: we registered time of simple visual motor reaction and time of visual motor reaction of choice; tapping test.

$501^{\text {st }}$ year students of 17-18 years' age, who were trained in physical rehabilitation group, participated in the research.

\section{Results of the research}

For determination of complex fitness structure of physical rehabilitation group's students we applied factorial analysis by principle component method (see table 1).

Table 1. Matrix of components in factorial analysis of complex testing indicators of physical rehabilitation group's students

\begin{tabular}{|c|c|c|c|c|c|c|}
\hline \multirow{2}{*}{$\begin{array}{l}\text { Description of } \\
\text { factor }\end{array}$} & \multirow{2}{*}{ Indicators } & \multicolumn{5}{|c|}{ Factors } \\
\hline & & 1 & 2 & 3 & 4 & 5 \\
\hline \multirow{6}{*}{ Power potentials } & Body length, $\mathrm{cm}$ & 0.776 & & & & \\
\hline & Body mass, kg & 0.644 & & & & \\
\hline & Dynamometry of right hand, kg & 0.861 & & & & \\
\hline & Dynamometry of left hand, kg & 0.867 & & & & \\
\hline & Ball passes in pars for $30 \mathrm{sec}$. & 0.659 & & & & \\
\hline & $\begin{array}{l}\text { Arms' bending-unbending in elbows with } 1 \\
\text { kg load for } 30 \mathrm{sec} ., \text { times }\end{array}$ & 0.530 & & & & \\
\hline \multirow{3}{*}{$\begin{array}{l}\text { Functional } \\
\text { potentials }\end{array}$} & Systolic blood pressure, mm.merc.col. & & 0.668 & & & \\
\hline & Diastolic blood pressure, mm.merc.col. & & 0.860 & & & \\
\hline & Keeping legs under angle of $45^{\circ}$, sec. & & -0.516 & & & \\
\hline \multirow{3}{*}{$\begin{array}{l}\text { Frequency } \\
\text { movements }\end{array}$} & ofTapping test, times & & & 0.772 & & \\
\hline & Throwing of tennis ball to target, times & & & 0.701 & & \\
\hline & $f_{\mathrm{f}}$ Time of simple visual motor reaction, m.sec. & & & & 0.821 & \\
\hline $\begin{array}{l}\text { Quickness } \\
\text { reaction }\end{array}$ & $\begin{array}{l}\text { Time of visual motor reaction of choice, } \\
\text { m.sec. }\end{array}$ & & & & 0.597 & 0.563 \\
\hline Coordination & Heart beats rate in rest, b.p.m. & & & & & 0.851 \\
\hline potentials & Romberg's test, sec. & & & & & 0.634 \\
\hline Variance, \% & & 25.23 & 12.54 & 9.84 & 9.15 & 8.06 \\
\hline
\end{tabular}

First factor (power potentials) included the following indicators: "body length" $(\mathrm{r}=0.776)$, "body mass" $(r=0.644)$, "dynamometry of right hand" $(r=0.861)$, "dynamometry of left hand" $(r=0.867)$ and "ball's passes in pairs for $30 \mathrm{sec."}(\mathrm{r}=0.659)$. Indicators of body length, body mass and hands' strength are interconnected: hands' strength increases with increasing of body mass. For increasing of relative strength, considering excess body weight, it is necessary to use exercises for removal of excess fat.

Second by significance factor (functional potentials) contained the following indicators: "systolic b.p." (r $=0.668)$, "diastolic b.p." $(\mathrm{r}=0.860)$, "keeping legs under angle of $45^{\circ}$ " $(\mathrm{r}=-0.516)$. These indicators are interconnected. The higher systolic and diastolic blood pressures are the less load of abdomen muscles can the tested endure. Low motor functioning of this contingent's students weakens functioning of most important muscular systems. It is the factor of reduction of cardio-vascular and respiratory systems' functional potentials.

Third factor (frequency of movements) included the following indicators: "tapping test" $(\mathrm{r}=0.772)$, "throwing of tennis ball to target" $(\mathrm{r}=0.701)$. It is not less significant: "fine motor skills" of hand indirectly is connected with operative thinking.

Forth factor (quickness of reaction) includes: "time of simple visual motor reaction" $(r=0.821)$ and "Time of visual motor reaction of choice" $(r=0.563-0.597)$. 
Fifth factor (coordination abilities) includes indicators of heart beats rate in rest $(\mathrm{r}=0.851)$ and Romberg's test $(\mathrm{r}=0.634)$.

Factorial analysis resulted in determination that the tested group is heterogeneous. One part of students has low fitness level, other - average. It can be explained by the fact that $1^{\text {st }}$ year students did not attend physical culture lessons, being pupils of school. Some pupils of special health group did not receive proper physical load, which was required for correction of their functional state, depending on disease.

Basing on the received data we produced the following recommendations on physical education of special health group's students. At first stage of educational process it is necessary to ensure as quick as possible recreation of functions, distorted by disease. For this purpose it is necessary to increase potentials of students' organism for practicing physical exercises though usual forms of motor functioning. At next stage it is required to start special trainings, considering disease of every student. It will ensure recreation of organism's general workability. At final stages of educational process it is necessary to train important motor qualities of this category's students.

In order to ensure complete compensation of available in physical rehabilitation group students' disorders, it is necessary to use basic variants of general physical and breathing exercises. Besides, purposeful work on formation of comprehensive motor potential with the help of aerobic loads, physical exercises of local and regional character is required. These recommendations facilitate increase of mental and physical workability through mastering of new physical exercises and motor skills [3, 14].

\section{Discussion}

Recent decades the quantity of special health groups' students has increased owing to reduction of health level [14, 21, 24, and 27]. Researchers [4, 15] confirm the data that students of this category can not master typical physical education program. The authors work out methodic and programs, which help students to strengthen their health and to raise physical fitness in process of physical education. Consideration of physical and psychophysiological potentials of physical rehabilitation group's students is an important factor for increasing of educational process quality. The main task of physical rehabilitation group's students is achievement of maximal health improvement effect and removal of residuals of their diseases. That is why in trainings it is necessary to use strictly differentiated means and methods, depending on students' diseases.

As a result of our research we supplemented the data of other authors [6, 8, and 17] about usage of factorial analysis for determination of structure of students' complex fitness. The authors found that factorial structure of main group girls' fitness differs by great complexity, comparing with boys. In our research we found specific features of factorial structure of physical rehabilitation group's students. It permits for teacher to correctly select physical load.

\section{Conclusions:}

The fulfilled factorial analysis permits to determine rational correlation of means and methods for increasing of physical fitness and health strengthening of physical rehabilitation group's students. It was found that the most significant factors in complex fitness of physical rehabilitation group's students were power and functional qualities. In this connection it was offered to correct the program of discipline "Physical education" and content of practical trainings at every stage of educational process.

The prospects of further researches imply working out of physical education program for physical rehabilitation group's students and determination of its effectiveness.

\section{Conflict of interests}

The authors declare that there is o conflict of interests.

\section{References:}

1. Barybina LN, Kozina ZhL. Description of psychophysiological indexes of students of different sporting specializations. Physical Education of Students, 2010;4: 6-11.

2. Bismak OV. Likuval'na fizichna kul'tura u special'nikh medichnikh grupakh [Therapeutic physical culture in special health groups], Kharkiv, Brovin RH; 2010. (in Ukrainian)

3. Bodnar I. Teoriia, metodika i organizaciia fizichnogo vikhovannia studentiv special'noi medichnoi grupi [Theory, methodic and organization of special health group's students' physical education]. Lviv, Ukrainian technologies; 2005. (in Ukrainian) 
4. Golod NR.,Principles of developing a well-rounded program of physical rehabilitation for female students in the special medical group with consideration of physical activity impairment. Pedagogics, psychology, medical-biological problems of physical training and sports, 2015;5:9-15. http://dx.doi.org/10.15561/18189172.2015.0502

5. Gurieieva AM, Klopov RV. Factor structure of physical state of female students of higher education institution. Pedagogics, psychology, medical-biological problems of physical training and sports, 2014;7:711. doi:10.6084/m9.figshare. 1015378

6. Ivashchenko OV, Yermakova TS. Assessment of functional, coordination and power fitness of 7-8 form boys. Pedagogics, psychology, medical-biological problems of physical training and sports, 2015;9:20-25. http://dx.doi.org/10.15561/18189172.2015.0903

7. Kozina ZL, Iermakov SS. Analysis of students' nervous system's typological properties, in aspect of response to extreme situation, with the help of multi-dimensional analysis. Physical Education of Students, 2015;3:1019. http://dx.doi.org/10.15561/20755279.2015.0302

8. Kozina ZhL, Sobko IN, Kolomiec NA, Jagiełło Władysław, Jagiełło Marina. Allocation algorithm for athletes group to form tactical tasks in game team sports using the methods of multivariate analysis (illustrated women Ukrainian team basketball with hearing impairments). Pedagogics, psychology, medical-biological problems of physical training and sports, 2014;12: 40-48. doi:10.15561/18189172.2014.1208

9. Kozina ZhL, Sobko IN, Prokopenko AI, Guba AV, Iermakov SS, Prusik Krzysztof, Cieślicka Mirosława. Methods of technical and tactical training basketball players with hearing impairments using innovative technologies. Physical Education of Students, 2014;3:30-39. doi:10.6084/m9.figshare.978699

10. Kozina Zh.L. Osnovnye polozheniia avtorskogo kursa podgotovki beremennykh k estestvennym zdorovym rodam "Raskrytie cvetka" [Main principles of author's training course for preparation of pregnant women to natural healthy childbirth "Opening of flower"]. Pedagogics, psychology, medical-biological problems of physical training and sports, 2008;3:81-92.

11. Kozina ZhL, Sobko IN, Klimenko AI, Sak NN. Comparative characteristics of psychophysiological features skilled basketball players-women with hearing and skilled basketball players healthy. Pedagogics, psychology, medical-biological problems of physical training and sports, 2013;7:28-33. doi:10.6084/m9.figshare.735962

12. Kozina Zh.L. Faktorni modeli fizichnoi pidgotovlenosti volejbolistok visokogo klasu riznogo igrovogo amplua [Factorial models of physical fitness of different game roles' elite female volleyball players]. Pedagogics, psychology, medical-biological problems of physical training and sports, 2007;9:80-85.

13. Kudelko VE, Ulaieva LO, Shevchenko OO. Pozitivnij vpliv vprav dlia rozvitku koordinacii u studentiv, iaki zajmaiut'sia fizichnim vikhovanniam u grupi LFK [Positive influence exercises for coordination on students, who train in TPC]. Pedagogics, psychology, medical-biological problems of physical training and sports, 2011;7:49-54.

14. Kudelko VE, Ulaieva LO, Sobko IM. Metodichni rekomendacii z navchal'noi disciplini «Fizichne vikhovannia» dlia studentiv special'nikh navchal'nikh grup usikh napriamiv pidgotovki [Methodic recommendations on discipline "Physical education" for students of special health groups of all directions of training], Kharkov: KhNUE; 2012. (in Ukrainian)

15. Kuzmin VA, Kopylov YuA, Kudryavtsev MD, Galimov GY, Iermakov SS. Substantiation of effectiveness of trainings on health related methodic for students with weakened motor fitness. Physical Education of Students, 2015;6:43-49. http://dx.doi.org/10.15561/20755279.2015.0606

16. Marakushin AI, Piddubnij OG, Cimbaliuk ZhO, Sobko IM, Cherednichenko AV. Robocha programa navchal'noi disciplini «Fizichne vikhovannia» za obranim vidom organizovanoi rukhovoi aktivnosti dlia studentiv usikh napriamiv pidgotovki dennoi formi navchannia [Working program of discipline "Physical education" by chosen kind of organized motor functioning for full time students for all directions of training], Kharkov: KhNUE; 2014. (in Ukrainian)

17. Prusik Krzysztof, Prusik Katarzyna, Kozina ZhL, Iermakov SS. Features of physical development, physical preparedness and functional state of boys and girls - students of Polish higher educational establishments. Physical Education of Students, 2013;1:54-61. doi:10.6084/m9.figshare.96415 
18. Sobko IN, Ulaeva LA. Razvitie vynoslivosti na zaniatiiakh po fizicheskomu vospitaniiu v gruppe LFK [Training of endurance at physical education classes in TPC groups]. XI Mezhdunarodnaia nauchnaia konferenciia "Fizicheskoe vospitanie $i$ sport $v$ vysshikh uchebnykh zavedeniiakh", 23 -24 aprelia, 2015, Khar'kov [9th International scientific conference "Physical education and sports in higher educational establishments", April, 23 -24, 2015. Kharkov], Kharkov; 2015. (in Russian)

19. Becker CM, Glascoff MA, Felts WM, Kent C. Adapting and using quality management methods to improve health promotion explore. The Journal of Science and Healing. 2015;11:222-228.

20. Cameron MH, Monroe L. Physical rehabilitation: evidence-based examination, evaluation, and intervention. St. Louis: Elsevier Health Sciences; 2007.

21. Goforth M, Almquist J, Matney M, Abdenour TE, Kyle J, Leaman J, Montgomery S.Understanding organization structures of the college, university, high school, clinical, and professional. Clinics in Sports Medicine, 2007;26:201-226.

22. Hong Xia M. Effects of different sports events on the physical self of deaf college students. Journal of Physical Education, 2010; 17: 55-59.

23. McLeod JD, Uemura R, Rohrman S. Adolescent mental health, behavior problems, and academic achievement. Journal of Health and Social Behavior, 2012;53:482-497.

24. Norma GC, Barton M, Bowles E, Scott BM. Multilevel analysis of student and school-level variables on students' health-related fitness. Medicine \& Science in Sports \& Exercise, 2015;47:47- 52.

25. O'Sullivan SB, Schmitz TJ. Physical Rehabilitation. Philadelphia: F.A. Davis Company; 2006.

26. Symons AB, Morley CP, McGuigan D, Elie A. A curriculum on care for people with disabilities: effects on medical student self-reported attitudes and comfort level. Disability and Health Journal, 2013;7:88-95.

27. Varela-Mato V, Clemes S, Cancela-Carral J. Physical activity and sitting time measured in Spanish university students. Journal of Science and Medicine in Sport, 2012;15:20-25.

28. Young Hui-Ju, Erickson ML, Johnson KB, Johnson MA, McCully KK. A wellness program for individuals with disabilities. Disability and Health Journal, 2013;8:345-352. 


\section{Information about the authors:}

Sobko I. N.; http://orcid.org/0000-0002-4920-9775; sobko.kh@mail.ru; Simon Kuznets Kharkov National Economic University; Lenina boulevard 9a, 61001, Kharkov, Ukraine.

Ulaeva L.A.; http://orcid.org/0000-0003-0468-756X; lorik2340@gmail.com; Simon Kuznets Kharkov National Economic University; Lenina boulevard 9a, 61001, Kharkov, Ukraine.

Yakovenko Y.A.; yulya.yakov@mail.ru; http://orcid.org/00000002-2888-8465; Simon Kuznets Kharkov National Economic University; Lenina boulevard 9a, 61001, Kharkov, Ukraine.

Cite this article as: Sobko I.N., Ulaeva L.A., Yakovenko Y.A. Factorial structure of physical rehabilitation group students' complex fitness. Physical education of students, 2016;2:32-37. doi:10.15561/20755279.2016.0205

The electronic version of this article is the complete one and can be found online at: http://www.sportpedu.org.ua/html/arhive-e.html

This is an Open Access article distributed under the terms of the Creative Commons Attribution License, which permits unrestricted use, distribution, and reproduction in any medium, provided the original work is properly cited (http://creativecommons.org/licenses/by/4.0/deed.en).

Received: 03.03.2016

Accepted: 19.03.2016; Published: 25.04.2016 